\title{
DAYLIGHTING BURIED RIVERS AND STREAMS IN TEHRAN
}

\author{
Behnam Andik $^{1^{*}}$, Amin Sarang ${ }^{2}$ \\ ${ }^{1}$ Master Student in Environmental Engineering-Water Resources, University of Tehran \\ ${ }^{2}$ Assistanse Professor in Water Recourses, University of Tehran \\ *Corresponding author email: andik@ut.ac.ir
}

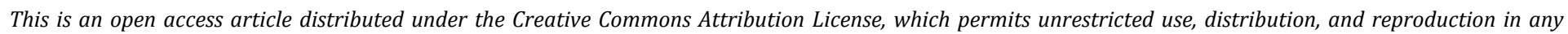
medium, provided the original work is properly cited

\section{ARTICLE DETAILS ABSTRACT}

\section{Article history:}

Received 12 October 2017

Accepted 12 November 2017

Available online 20 Disember 2017

\section{Keywords:}

Daylighting, Restoration, Tehran, Urban Streams, water quality

\begin{abstract}
The structural point of view which dominated decision makers and decision designers in urban management has been causing a lot of problems. Different cities got closer to the rivers and even a part of the stream have buried in the culverts in cities such as Tehran to maximize the use of the land on the riverbank and the bed. Ideas about the natural elements in the cities have been changed over the time. The emerging of concepts such as green infrastructure and low-impact development rise to the daylighting projects. Daylighting process reagents project that all or a part of the stream, creek or drainage system excavate from underground and open to fresh air and then take steps such as remediation, rehabilitation and restoration can be done for it. The delighted stream can raise property values and investment opportunities, creating public open spaces and reduce maintains costs for buried channels. Dominated structural considering for flood control cause problems for Tehran's streams and rivers, such as diverting to rigid channel and narrowing channel, over polluting by wastewater entrance, burying beneath covered channel and culverts, concerted bed, diverting from the main direction, etc. Rehabilitating and restoring Tehran's streams and rivers can reduce problems caused by flood and improve environmental quality too. Based on this regard, there is no legal gap and will not have the financial burden of the municipality in the long-term period so it seems daylighting streams in Tehran can be done as soon as possible.
\end{abstract}

\section{INTRODUCTION}

River restoration is one of the most prominent areas of applied water resources science. From an initial focus on enhancing fish habitat or river appearance, primarily through structural modification of channel form, restoration has expanded to incorporate a wide variety of management activities designed to enhance river process and form [1].

The structural point of view which dominated decision makers and decision designers in urban management has been causing a lot of problems, which is involved some of the cities about three decades after introducing sustainable development principle, specifically cities developed around rivers. Passing rivers from the downtown and economic exploitation cause degradation of these natural elements. This change exceeds urban streams as in most cases buried or their floodplain was developed to use land as much as possible [2].

Comprehending river engineering is essential to understand how humans treat rivers. There are four main eras for river engineering after the industrial revelation, as Ibrahimnejhad [3] explained: 1- from the 1750s to 1900 s that contain gigantic development to shipping, flood control and using land in flood plains. 2- From the 1900s to 1940 s is the second era and contains developing technologies to building huge dams and spreading them in North America, Europe and southwestern of Asia. Construction of Hoover Dam is one of the incredible events during this period; the first gigantic dam was built on Colorado River and complete in 1936. 3-the third era is referred to the 1950s to 1980 and is the crown of damming and deviating waters activities throughout the world. 4- In The fourth career, which is started from the 1980s and continued to now dam trend is decreased to 500 dams in the world, and more attentions paid to approaches like restoration and protecting Rivers as well as the effects of in-stream structures on streams' morphology and regimes.

Parts of the world are transferring from damming procedure toward removing them in the current period. Removing two large dams on Elwha River in Washington is done at this time as well as daylighting and restoring urban streams' project [4]. The necessity of proper movement to exit the present condition, i.e. the Structural point of view and the damages from the flood, the assuming flows as a treat and looking at the stream as a channel to transfer flood as well as move to thought of usefulness of natural elements such as streams and rivers requires to recognize possible practices and used steps to achieve these aims to be able to choose the best action for these disturbed streams; based on their current situation and socio-economic, political and technical restraints.
In recent years, many studies have been done in stream daylighting and restoration. Morandi et al. [5] used their online census [6] to identify potential interviewees involved into evaluating success and failure of french restoration projects. Kail et al. [7] used a meta-analysis to assess the effect of river restoration on fish, macroinvertebrates and aquatic macrophytes. Bergstrom and Loomis [8] conduct an economic valuation of river restoration to analysis the valuation literature and its uses in decision-making. Wohl et al. [9] published a review article in the science and practice of river restoration. Gonzalez et al. [10] made a global review in implementation and evaluation approaches to the restoration of riparian vegetation. Many Projects like Cheonggyecheon, Isar plan and etc. are done for this aim.

\section{MATERIALS AND METHODS}

Civil and environmental engineers, hydrologists, ecologists, biologists and even economists are experts who contribute in a restoring project. As a daylighting project is done by a group of different experts, it is essential to make a distinction between terms are used for this process [11]: Daylighting, rehabilitation, remediation, restoration.

\subsection{Daylighting}

The begging of the 21st century was coincided with approaching to an evolutionary point of urban runoff management for United States. Achieving to this point was accelerated by degradation and inefficiency of precast pipes constructed for collecting runoff and transferring stream and creek's water, which interrupted their physical development in the 19th century and was conveyed to buried canals and pipes for overusing flood plains and beds [12]. Cities in Iran also approached to riverside and riverbed to use land as much as possible, parts of streams buried in cities like Tehran, unfortunately.

The imagination and finally developing interactively a city which has water body become possible by initiation of environmental consciousness and monitoring. Emerging knowledge of daylighting urban streams is a valuable and viable tool for this future. Uniting these tool with other low impacts green infrastructure can cause socioeconomical, ecological and engineering benefit simultaneously [12].

Although the green infrastructure concept emerged in the industrial revolution era, it was defined completely centuries later by Pinkham [13] as "an interconnected network of green spaces, which conserve natural functions and values of ecosystems as well as provide benefits for humans." 
Daylighting urban stream is one of the green infrastructures manifests, which is trying to find a dynamic and complicated water process in streams surrounded by anthropogenic developments. As times go on and the attitudes about surface waters in the metropolitan environment changed, it could be said that daylighting concept is one of the most radical concepts in the green infrastructure revolutionary. Rules and plans of many countries are improving water quality considerably. Law makers, engineers, and constructor have been understood the value of maintenance and conserving natural drainage patterns and streams channel in new developments. In some places, people are paying attention and revegetating disrupted conduit of streams to restore their functions and beauties [14].

The stream which buried in underground culvert cause destruction to the environment. Small streams are highly efficient in scrubbing pollution from runoff and auto emissions; therefore, they are critical to the health of the entire watershed [15]. Culverts buried underground instead of having this cleaning capacity, transfer pollution to rivers rapidly and cause erosion. Culverts almost cause emerging bottleneck in runoffs conveyance systems and thus leading floods as well as they have no specific value to Wildlife [16].

Daylighting term is describing projects in which a part or entire of a river, creek or water drainage system which was buried before, emerge to sunlight. Usually, Daylighting projects pulled out streams from buried pipe and opened to free air [11].

A daylighted creek is a creek which its channel excavated from underground and restored. Daylighting is trying to restore streams to their original channels or threating them in a new, open channel between buildings, parking lots, and ballfields. Storm water pipes also can be daylighted or replaced with naturalized swales, constructed wetlands, or rehabilitated estuaries.

Daylighting is a new tool. Although in 1970 projects were done in Napa, California, and Illinois, shrubbery creek daylighting project in a park in Berkeley, California at 1984 is known as the primary sample of daylighting [13].

Broadhead and Lerner [14] present an intelligible picture [Figure 1] from the effects of daylighting process. This picture show tree streams after and prior to this process. The top photo shows a stream, which follows from a residential district in Zurich, Switzerland, left one present stream situation before daylighting, buried stream is shown by black dots. The right part shows daylighted stream and children who are playing around it. The middle part shows Saw Mill River in New York City. The third part is showing Cheonggyecheon River in Seoul, South Korea, which is one of the biggest daylighting projects around the world. In this project, a highway in the city downtown had been removed, a buried stream excavated and the city center was restored.

Buchholz et al. [17] reviewed previous studies and reminds that improvement of riparian habitat and water quality in newly created banks as well as the reduction of flood effects by increasing adsorbing capacity than culverts are parts of daylighting stream's benefit. If a daylighting process is coincided with increasing tree canopy, then reductions of heat islands' effects and green gases is imaginable for this activity [18]. Many communities have been understood that cost of daylighting is less than designing new pipes and culverts [19]. Daylighted streams could increase the value of real estates and investment opportunities in redevelopment area near these streams, return urban open spaces to dense part of the city and reduce city's cost by replacing degrading culverts with the natural open channel, which are easy to maintain. Daylighted streams are psychologically beneficial as they establish a path to connect to nature $[13,18]$

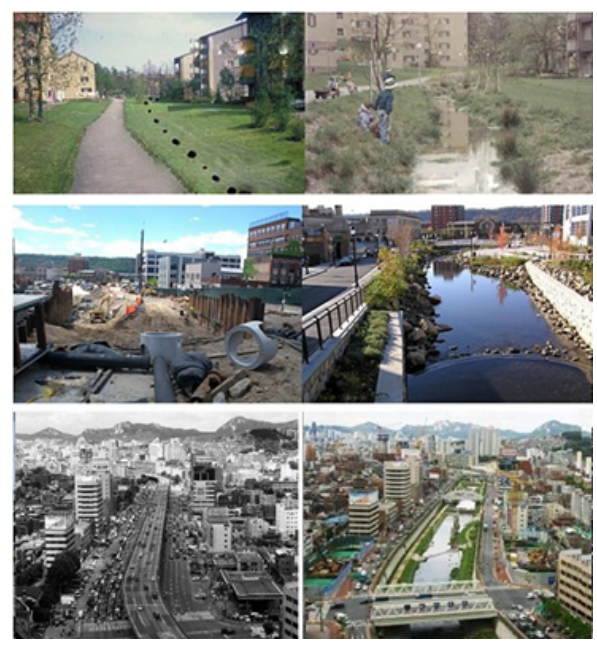

Figure 1: Samples of Daylighting Project, with a little change [14]

\subsection{Rehabilitation}

A rehabilitation project ideally is capable of returning the river to its primary status. This primary status includes rehabilitation of natural water quality, stream's sediment and its regime, canal geometry, aquatic plants, and animals as well as river banks. Although rehabilitation is an ideal act, cannot be achieved easily, because at the first it is difficult to identify the primary situation in the river and then in river management this concept will be meant that the entire river, from upstream to the downstream, have to be returned to its original situation, simultaneously. Because of the relationship between different parts of a watershed, Rehabilitation's aim can be achieved by rehabilitating the whole network of waterways and the whole area within the watershed. Achieving this aim is difficult and maybe impossible [11].

\subsection{Remediation}

Because of the high intensity of disturbance and an Irreversible situation in the river rehabilitation is not conceivable so attaining original ecosystem is not reasonable in some cases. The aim of remediation is improving ecological situation [6] of a river to achieve a sustainable ecosystem. In remediating river, it is not necessary for river situation to be the same as original situation. Sometimes in common literature of river management remediation cover a widerange concept which includes restoration activities. Remediation of a river leads to create a new ecosystem, which is more sustainable than the existing ecosystem but do not address to achieve the original ecosystem [11]. Notice that the Cheonggyecheon project was a daylighting project and then a remediation project because the newly created stream has no similarity with the stream before it had disturbed [20].

\subsection{Restoration}

Gore [21] asserted that "river restoration is the process of retrieving the watershed. Improvement and promotion caused by retrieving enabled river or stream's ecosystems to sustain habitat development and immigration to it with a more rapid speed than the natural physical and biological process. The improvement achieved by restoration cause returning to an ecosystem which is similar to adjacent areas lacking this kind of stresses.

Cairns [22] defined complete restoration process as follows: complete restoration implies the complete functional or structural return to the situation before disturbance completely. Restoration programs must have the aim of creating a system which has sustainable conduct or a channel with dynamic equilibrium, which supports a self-sufficient and functionally diverse community.

Although the primary status is only simulated by improving main elements of waterway's environment, valuable habitat is created and cause improving the ecosystem. Because of disability in rehabilitation, restoration is the common aim to be achieved by individuals and groups who are trying to. As depicted in Figure 2 restoring a river is a gradual process to improve river's ecosystem by structural practices like eliminating obstacles and unnecessary engineering actions as well as non-structural and management practices to achieving the original situation of the ecosystem. It is also obvious that complete restoration of a stream is rehabilitation.

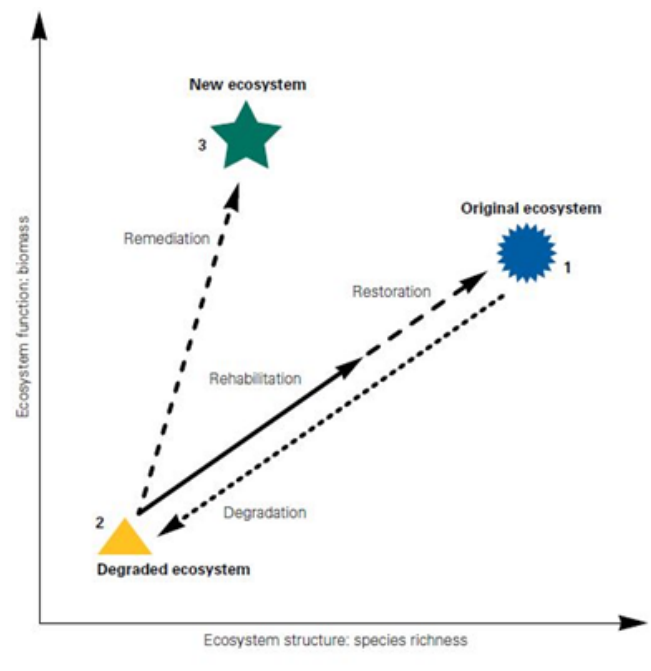


Figure 2: Different between Restoration, Rehabilitation and Remediation [22]

\subsection{Benefits of restoring streams}

Although benefits of daylighting are imaginable for restoration, it must be urged that sound function of a river is attractive and charming for residents and business owners. Enthusiastic people who enjoy riverside's elements and activities related to, conserve river's health in long-term. These benefits include cost effective flood control, improved water quality, reduced infrastructure costs, raised property values and generate new tax revenues as well as supporting tourism [16].

\subsection{Rivers and streams in Tehran and their issues}

There is six major valleys in Tehran in which water flows. By moving from the right side of Tehran to the left one Darabad, Darband, Darakeh, Farahzad, Kan and VardAvard are located. Valleys are Vshape in the north part of the city and almost covered by concrete channel in the middle part of the city because of the antiquity of urban pattern and the low depth of rivers. Tehran Urban Research and Planning Center affiliated with Tehran Municipality describe Tehran's main Valleys as follows [23]:

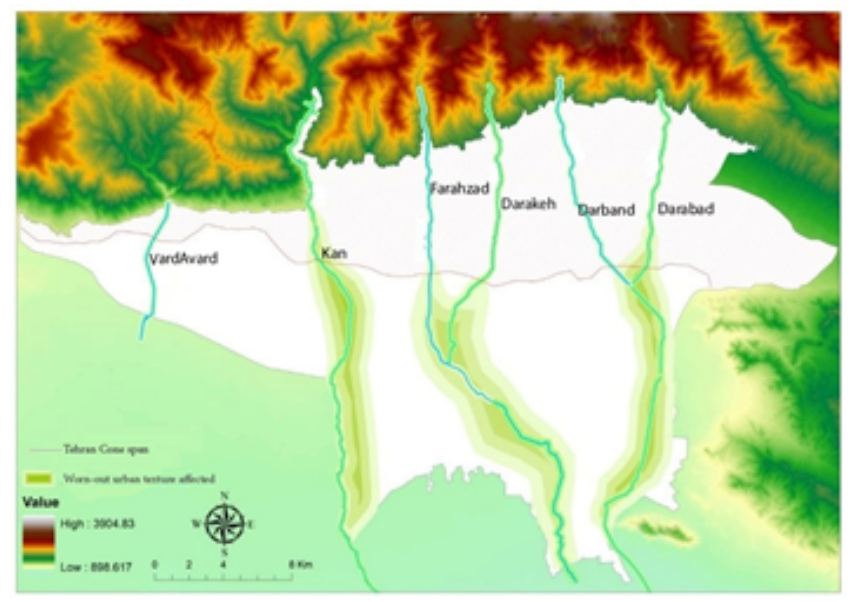

Figure 3: Natural Status of Tehran Rivers [23]

1. Darabad River is located in the eastern part of the city and originated from Tochal Mountain in the north of the capital and after passing through Darabad village and Ozgol highway buried in a channel and follows underground.

2. Darband River originated from Darband village and after passing through the Darband Valley and surrounded restaurants and coffee shops in the valley redirects to an open concrete channel and finally meets GolabDareh in Tajrish square.

3. Darakeh River is originated from Shahneshin Mountain and after passing through Evin House of Detection follows to the south of Tehran, parallel to Chamran highway.

4. Farahzad River is also originated from Alborz Mountains in the north. This river passes the Farahzad and Pounak villages, flows to Mahtab Chanel and finally meets main west floodway of Tehran.

5. Kan is the longest river, located in northwestern of the city and pass through five districts of Tehran and provide water for Chitgar Lake.

6. Vardavard River is also originated from northern of Tehran city and follows throw eastern districts of this city.

Transferring rivers to concrete channel and narrowing their conducts, over contaminating by entry of wastewaters, burying into covered channels and culverts, concreting bed, diverting flows from their main path, straitening meander and etc. are some of the issues involved urban streams and rivers in Tehran. Aforementioned issues are almost common in other city and urban streams through the world $[24,25]$.

\subsection{The history of river engineering projects in Tehran}

Being exposed to flood cause changing the ideas and viewpoint of the urban planners about runoff in Tehran from a natural, useful and necessary element to a bothersome element, which obstacle physical development of city; thus in the studies and plans conducted related to runoff and urban streams the dominant idea was trying to convey runoff and flood water from urban districts to outside of city. According to Plans and practices were taken in this city, it is obvious that point of view about rivers and streams in borders of the city is not a view as a natural conduct and live ecosystem but is a channel to convey the flood stream from urban developed area to outside of the city. In Figure 4 four Comprehensive Surface Water Studies is depicted.

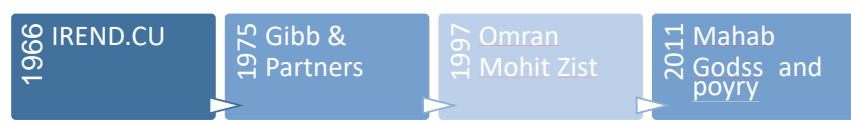

Figure 4: The history of integrated studies on surface water in Tehran

The history of studies related to controlling, collecting and leading Tehran's surface waters return to 1960 s when the first assessment conducted by IREND.CU consulting engineers in 1966 titled as Studies for Controlling Flood Water in Tehran. The aims of the project to be achieved were mentioned as preventing mountain's flood from interring to the city and controlling urban floods; therefore, by this point of view to urban streams and runoffs, the principles of the project were mentioned as follows:

1. Build two main floodways in the west and the east of city to restrain mountain's floods from interring to the city.

2. Present a proposal to build Shahrdari and Khayam Tunnels to reduce flooding issues in city

3. Present a Proposal to build Shahbaz Tunnel in the east and Navab tunnel and Firoozabad Channel in the west of Tehran to lead and convey eastern and western surface water.

4. Present a Proposal for improvement and fixation of the lateral wall of multiple waterways interring to the city.

5. Reopen and remove some of the bottlenecks, specifically at $\begin{array}{llll}\text { inappropriate bridges and } & \text { culverts. }\end{array}$

In 1975, Gibb \& Partners conducted a study with the aim of preparing an integrated plan for drainage of areas covered by 25-year Tehran City Development Master Plan for conveying river's stream from the city's border to outside of it.

The point of view about being harmful was promoted by conducting studies of Tehran Water Surface Master Plan in 1993 by Omran Mohit Zist Consulting Engineers [26]. In the last study, which done by a joint of Mahab Ghods and Poyry companies followed issues was addressed: Immunization city against flood and sediments, environmental issues, using the new approach to measure flood, monitoring surface water network, socioeconomic and legal considerations, the need of establishing guideline and codification for operation and maintenance as well as creating a special organization to manage surface water in Tehran [27].

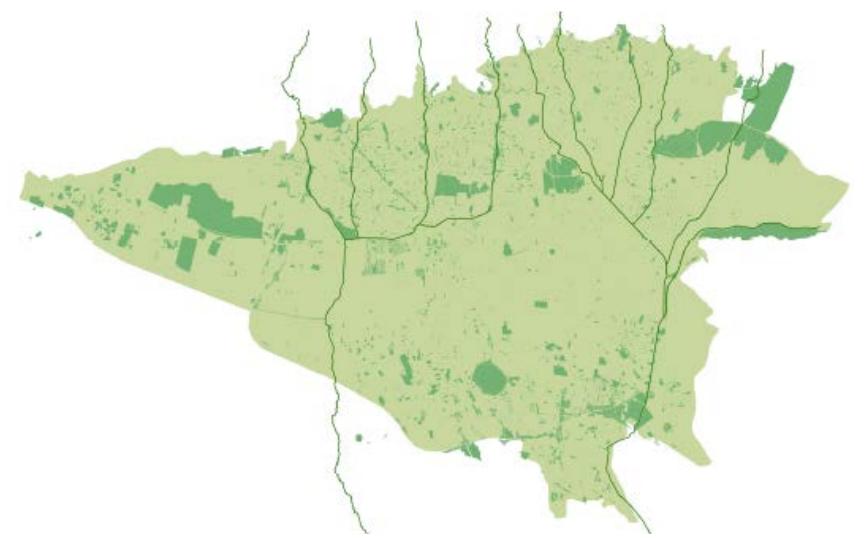

Figure 5: Tehran's Streams Statuses after madding 2 main waterways [28]

The Second Five-Year Plan of the Tehran Municipality, which is prepared for 2012-2016 contains laws that obligate Tehran Municipality to remediate surrounded valleys in the city. A part of the article urged that "with the aim of sustainable development, promoting safety and environment as well as in the event of integrated management of Tehran's rivers and kariz remediation and restoration, Municipality is obligated to establish a master plan in cooperation with the Ministry of Energy for restoring Tehran's main rivers: Kan, VardAvard, Farahzad, Darband and Darabad." In These years, some plan was launched and finished, and some others are underway." 


\section{RESULT AND DISCUSSION}

\subsection{Steps needs to restore Tehran's stream}

Returning to the original and primary status in Tehran's valleys at the first step requires reducing flood's hazard and removing dual floodways and their related drainage systems. The world experience has shown that river's restoration process is a time-consuming process and not a short-term activity. At the second step simultaneous with first, it has been necessary to try for daylighting and restoring natural streams and utile their benefits to reduce flood and water pollution as well as improving air quality. Proposed frame to return to the natural condition in Tehran valleys is as mentioned following:

\subsubsection{Reduce flood hazard.}

a.) Reduce impervious surfaces using pervious pavement b.) Penetrate street runoff by implementing Best Management Practices (BMPs) such These include detention ponds, bioretention ponds and swales, cisterns, storm-water planters, and infiltration ponds.

c.) Try to reduce flood at upstream of the watershed by using watershed management practices and revegetating riparian to obstacle entry of sediment and bed erosion 3.1.2 Daylight buried streams. a.) Recognize buried streams by available maps. b.) Recognize reference reach to restore the stream c.) Prepare and establish multiple buffers to buy lands and implement the restoration program in plan's perspective d.) Remove obstacles in multiple buffers in plan's perspective e.) Daylight streams in plan's perspective. Implementing aforementioned steps require providing financial support and legal commitments to launch daylighting buried stream process and finally restoring them. Regional Water Authorities as a part of Ministry of Energy and responsible for managing rivers affairs are obligated to define streams' bed and their buffer zones according to a bill passed by the cabinet of ministers [29]. Two guidelines are passed based on this bill.

Guideline for determining the buffer zone of rivers urged that the buffer for natural creeks, rivers and streams, marshes and natural ponds for dredging and operation practices is $1-21 \mathrm{~m}$ from the edge of the riverbed.

$$
F=1.4 \sum_{i=1}^{5}\left(w_{i} * f_{i}\right)
$$

River's buffer zone must be calculated based on DLSRS approach which D is standing for 25 years flood discharge index, L is standing for Location index, $\mathrm{S}$ is stability index, $\mathrm{R}$ is the regime index, and the second $\mathrm{S}$ is standing for Social Tension index. There is a predefined zone width for each one of aforementioned indexes. The final buffer zone is calculated based on the following equation in which $F$ is final width of Buffer, wi is weight of each parameter, and fi is the buffer for ith index. Assessing the existing laws related to rivers and streams showed that law makers not only confirmed allowance for daylighting and restoring streams but also clearly prohibit construction and development in this zone.

In Guidelines for Determining the Bufferzone for Quality of Surface Waters, the buffer zone for a group of surface-water bodies, which are not drinkable or are not in the protected category of ponds and rivers divided into three zones which the land use for each zone is mentioned in this guideline [30].
As previous studies indicate [19. Municipality can provide required financial resources in long-term to daylighting and restoring buried streams in Tehran by saving the budget spend on maintaining surface water collection systems.

\section{CONCLUSION}

Altering the point of view of flood and urban streams in the previous decades caused changing Structural point of view dominated urban management officials and decision maker. The advent of concepts like green infrastructure, low impact development, and sustainable cities causes altering attitudes about urban streams; daylighting and restoring urban streams are caused by altering this attitude. Daylighting buried streams is initiated in all over the world, and its socio-economic and environmental benefits are approved.

Tehran city also uses this approach by utilizing structural elements like concrete waterways and drainage systems as well as using in surface water development plans. Emerging problems and issues in this city by omitting natural streams caused considering sustainable and eco-friendly approaches in addressing problems caused by floods. The existence of rules and guidelines issued about rivers and streams by the upstream institutions and socio-economic and environmental benefits achieved by restoring streams can be an incentive for restoring streams and rivers in Tehran city; stream and rivers which their main riverbed is covered or destroyed by diverging and conveying to concert channel.

\section{REFERENCES}

[1] Wohl, E., Lane, S.N., and Wilcox, A.C. 2015. The science and practice of river restoration. Water Resources Research, 51 (8), 5974-5997.

[2] Sarang, A., Andik, B., and Ardestani, M. 2015. Ecological Riverfront Design, first ed., Khaniran, Iran, [in Persian].

[3] Ibrahimnejhad, M. 2005. River's Ecology: Function and structure of surface water, University of Isfahan Publication Center, [in Persian].

[4] Warrick, J.A., Bountry, J.A., East, A.E., Magirl, C.S., Randle, T.J., Gelfenbaum, G., Ritchie, A.C., Pess, G.R., Leung, V., and Duda, J.J. 2015. Large-scale dam removal on the Elwha River, Washington, USA: source-to-sink sediment budget and synthesis. Geomorphology, 246, 729-750.

[5] Morandi, B., Piégay, H., Lamouroux, N., and Vaudor, L. 2014. How is success or failure in river restoration projects evaluated? Feedback from French restoration projects. Journal of Environmental Management, 137, 178-188.

[6] Morandi, B., and Piégay, H. 2011. River restoration experiences on the web: operational outcomes and perspectives. Natures Sciences Sociétés, 19 (3), 224-235.

[7] Kail, J., Brabec, K., Poppe, M., and Januschke, K. 2015. The effect of river restoration on fish, macroinvertebrates and aquatic macrophytes: a meta-analysis. Ecological Indicators, 30 (58), 311-21.

[8] Bergstrom, J.C., and Loomis, J.B. 2017. Economic valuation of river restoration: An analysis of the valuation literature and its uses in decision-making. Water Resources and Economics, 31 (17), 9-19.

[9] Wohl, E., Lane, S.N., and Wilcox, A.C. 2015. The science and practice of river restoration. Water Resources Research, 51 (8), 5974-5997. 